\title{
David Hiley
}

\section{Some Medieval Relics of Saints' Plainchant Offices}

\begin{abstract}
The transmission of cycles of office chants for local saints often follows a path different from that of the main body of liturgical chant. While some offices were known across a fairly large area, others were restricted to only one diocese, or even a single institution. The value of fragments of such offices varies correspondingly. Examples are discussed from the offices for Emmeram, Vitus, Catherine, Margaret, Afra, and George. The problems they present concern variously the liturgical occasion and order of the chants, their musical notation, and their place in the wider tradition of medieval chant.
\end{abstract}

The transmission of cycles of office chants for local saints - sometimes called historiae - often follows a path different from that of the main body of liturgical chant. In earlier sources, with small, compact script and notation, a historia with between twenty and forty chants could easily be accommodated in a single gathering, perhaps no more than half a dozen leaves. No doubt all historiae were first recorded thus, before eventually finding their way into a full antiphoner or notated breviary, sometimes clearly as additions to the older, established repertory. A few are to be found together with the vita of the saint, and in some cases vita and historia were written by the same author/composer. ${ }^{1}$ One cannot always know if a particular fragment comes from a libellus of this sort, or from a larger service book.

Historiae were made to enhance the veneration of a particular saint in a particular area or institution. Depending on the importance of the saint, cycles might be known across a fairly large area (e.g. Afra throughout all of Southern Germany), or in only one diocese (e.g. Corbinian in the diocese of Freising), or only one institution within that diocese (e.g. Marinus and Anianus at the Benedictine monastery of Rott-am-Inn, Juliana at Schäftlarn, Quirinus and Chrysogonus at

1 Berschin 1975; Hiley 2015a.

๖ Open Access. (๐ 2020 David Hiley, published by De Gruyter. (cc) BY-NC-ND This work is licensed under the Creative Commons Attribution-NonCommercial-NoDerivatives 4.0 International License.

https://doi.org/10.1515/9783110717884-004 
Tegernsee, Mechthild at Diessen). ${ }^{2}$ The value of fragments of such offices varies correspondingly.

The number of fragmentary remains is at present impossible to assess accurately, but is certainly very large. While the investigation of saints' offices has naturally concentrated on fully preserved cycles, significant contributions to research have been made, such as the work of John Toy on fragments of English saints' offices in Scandinavian libraries. ${ }^{3}$ As examples of those presently known, one might mention just four: for Oswin of Deira a substantial amount can be recovered, yet not a full cycle; for Alban and for Augustine of Canterbury only a handful of chants are known from sources in staff notation, for Etheldreda of Ely only a small fragment survives. ${ }^{4}$ In the following, I shall discuss six examples: not, however, from England but from southern Germany. Each example raises questions either about the original function and transmission of the chants, or about our resources and methods of investigation.

\section{Munich, Bayerische Staatsbibliothek, Clm 29316(38 - Emmeram}

My first examples are three leaves from a twelfth-century antiphoner preserved in the Bavarian State Library in Munich, under the shelfmark Clm 29316(38. The original book was certainly quite large, $19 \times 26.5 \mathrm{~cm}$. Two of the leaves are known to have been taken from a book from the Benedictine monastery at Tegernsee, and Hermann Hauke was able to add a third to them. ${ }^{5}$ Very probably they are the remains of a Tegernsee antiphoner, and the order of chants follows the Benedictine cursus. The first leaf in order of the liturgical cycle has chants for one of the summer Sundays (De Sapientia), while the second leaf has office chants for the Assumption of Mary (15 August), the Beheading of John the Baptist (29 August) and the Nativity of Mary (8 September). Then there is another gap, yet not a large one: the third leaf has a good part of the office for St Maurice (22 September) - most of the Second Nocturn, the Third Nocturn, and Lauds - and then just the

2 Editions and studies are gradually making the wealth of material from this area better known. See, for example: Hiley/Berschin 2004; Hiley 2014; Klugseder 2008a.

3 Toy 2009.

4 Hiley 2015b.

5 Three very useful volumes describing fragments in the Bayerische Staatsbibliothek have been published, following the reordering of the sources according to liturgical type: Hauke 1994-2013. For Clm 29316(38 see vol. 2 (2001), 50. 
start of an antiphon for St Emmeram of Regensburg, who shares the same feast day (see Figs 1a and 1b). Maurice obviously had priority over Emmeram at the monastery where the antiphoner was used; presumably the antiphon for Emmeram was for the Magnificat at Second Vespers, where he could be commemorated.

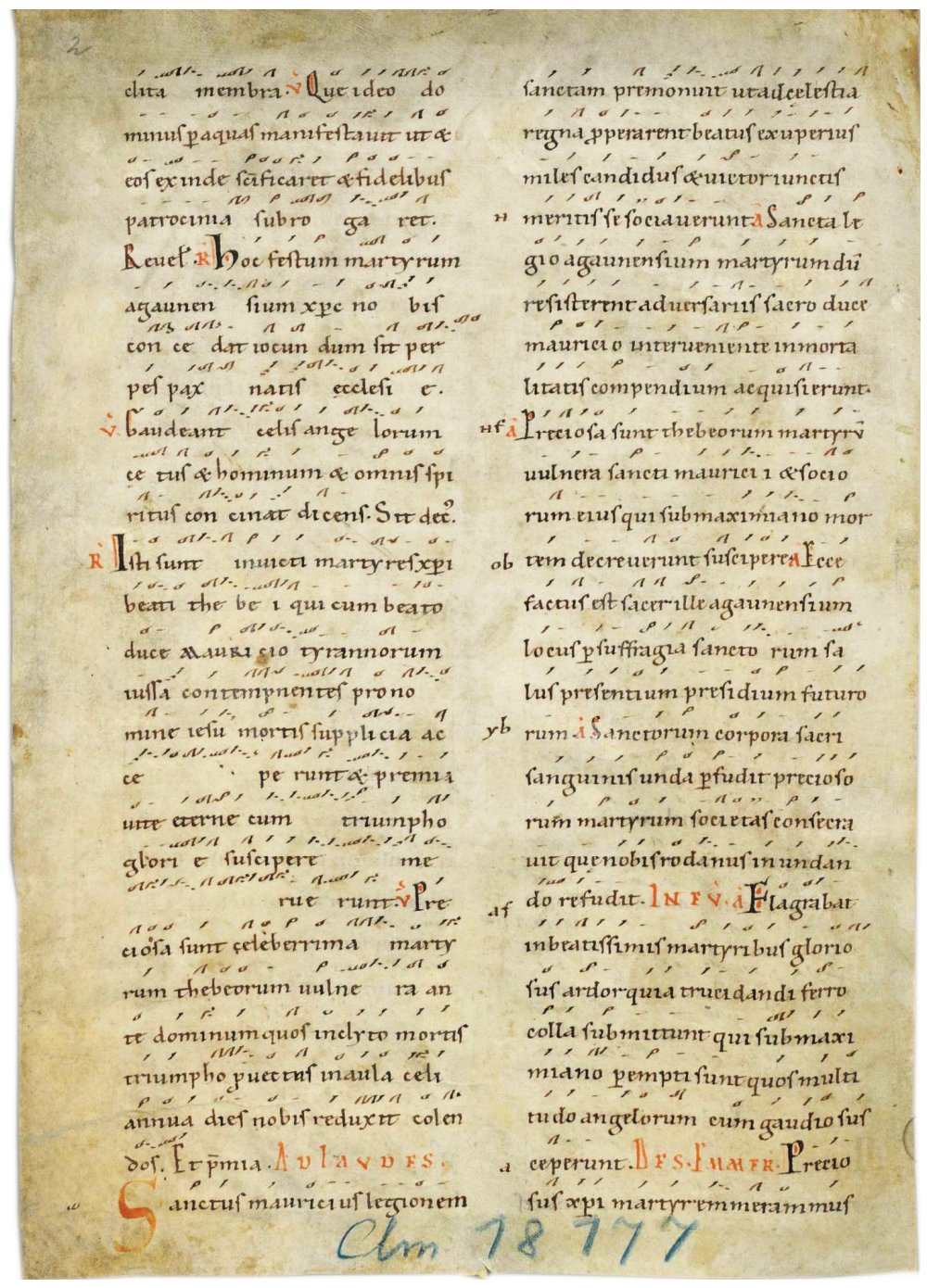

Fig. 1a: Munich, Bayerische Staatsbibliothek, Clm 29316(38, f. 3v; (C) Munich, Bayerische Staatsbibliothek. 
The Emmeram antiphon, Preciosus Christi martyr, is a very rare item. The situation is somewhat complicated. The story begins toward the end of the eighth century. Manuscript Paris, Bibliothèque Nationale, lat. 2990A, according to Bernhard Bischoff from the circle of Arn, abbot of Saint-Amand and bishop (later archbishop) of Salzburg, contains the vita of St Emmeram written by Arbeo of Freising about 770, followed by the texts of a full cycle of Matins chants (but neither Vespers nor Lauds) for the saint's feast day. While it is certain that at least some of these chants were sung in Regensburg, around 1030 the monk Arnold of the Benedictine monastery of St Emmeram composed a new cycle, and almost all preserved sources of Emmeram chants have Arnold's cycle. ${ }^{6}$ However, a fragment written in the late tenth or early eleventh century, originally from St Emmeram's and now in the Lilly Library at the University of Indiana in Bloomington, has eight 'pre-Arnold' Emmeram chants, or the remains of them.

We have no other Regensburg sources for this office, only for Arnold's new cycle. ${ }^{7}$ However, Barbora Kabátková recently made the surprising - and very welcome - discovery that a form of the older Emmeram office was still sung in St George's Prague in the twelfth century. A St George's antiphoner with staff notation enables us to transcribe all the old antiphons, but only three of the nine old responsories are used. What about the fragment Clm 29316(38 from Tegernsee? The antiphon, of which just the start is preserved, is the opening antiphon in Indiana and Prague, where it functions as the Magnificat antiphon at First Vespers; it is not in Paris 2990A, which has only the Matins cycle. We may conclude that in Tegernsee, on St Maurice's Day, it was customary to include a commemoration of Emmeram, and the antiphon still used at Tegernsee in the twelfth century was one dating back at least to the tenth century, perhaps even to Carolingian times.

\footnotetext{
6 We have what may be Arnold's autograph in Munich, Bayerische Staatsbibliothek, Clm 14870, which contains one of the two books he wrote about the St Emmeram, then the historia.

7 See Yeager 2009. The relationship between the source in Paris (early ninth century) and the fragment in Indiana (up to two centuries later) is not clear. Yeager argues that Indiana retains something of a yet older version, of which the Matins cycle in Paris is a revision.
} 


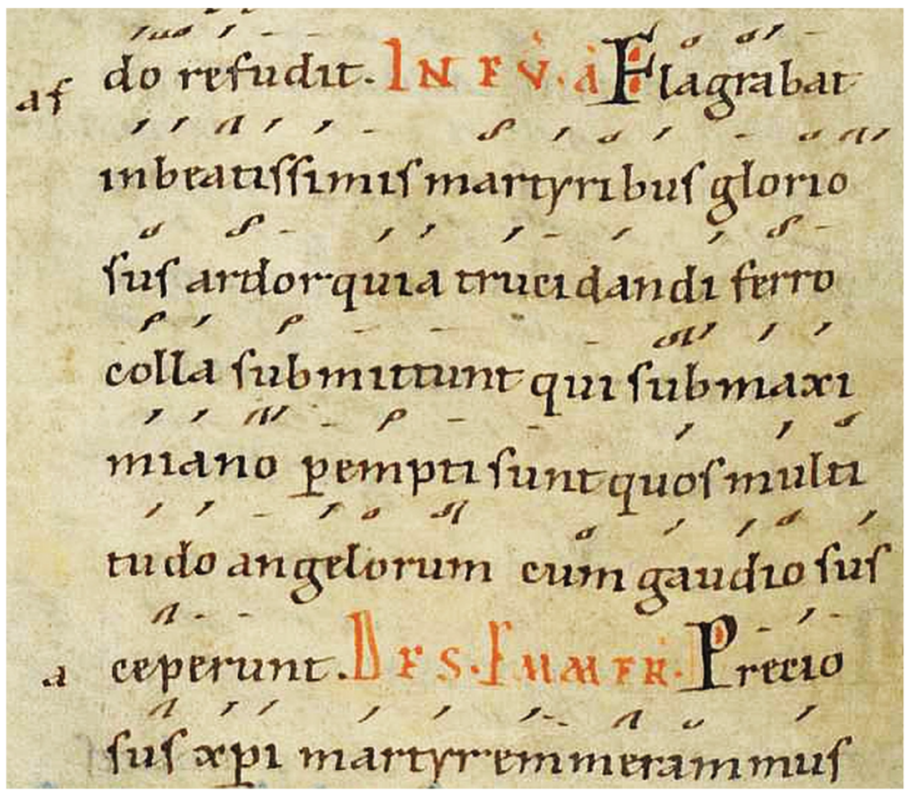

Fig. 1b: Munich, Bayerische Staatsbibliothek, CIm 29316(38, f. 3v (detail); (C) Munich, Bayerische Staatsbibliothek.

\section{Munich, Bayerische Staatsbibliothek, Clm 536 - Vitus}

It is extremely fortunate that so much of the Carolingian office for Emmeram can be transcribed. There are numerous examples where this is not the case. One may be found in Munich, Bayerische Staatsbibliothek Clm 536, a book of miscellaneous, non-liturgical content written mostly in the Benedictine monastery of Prüll, on the south side of Regensburg, which can be dated fairly exactly to the 1140s. On $\mathrm{f} .1$ there is a drawing of the patron saint of the monastery, Vitus, and Abbot Wernher (1143-1147). At the back of the book are several leaves $(14 \times 20 \mathrm{~cm})$ with a liturgical office for the saint (see Fig. 2):

f. 136v 1V-Am (hexameters)

$$
\text { M-I, M-A1-A5 }
$$

f. 137r M-A6, M-R1-R3

f. 137v M-R4, M-A7-12 


\section{frlager fanch vic}

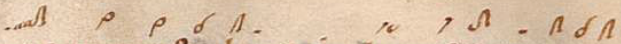

uvs umenfa des sume buruf fefta dre

Flor lucamorum '

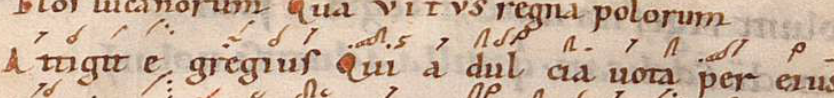

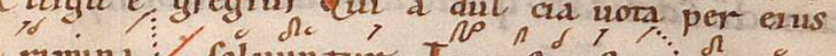

( rmina I foluuntux Tompeftaref re promunzá

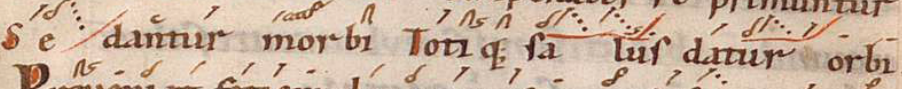

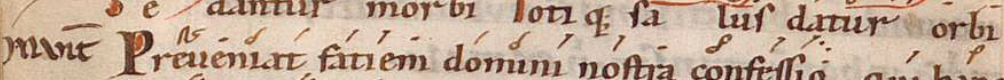

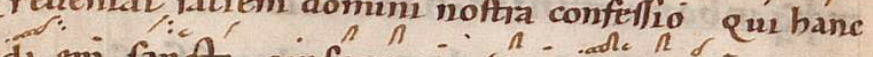
di eni fanch confectaure visi margrizo.

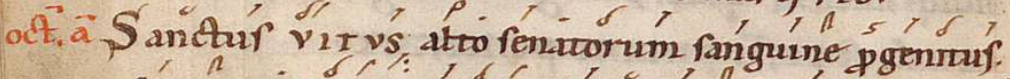
In prouincia lucánía préencí unte gaudá contemp

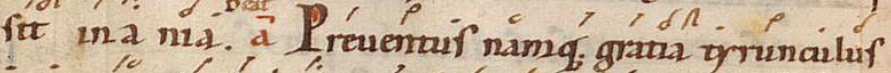

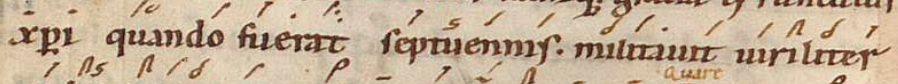

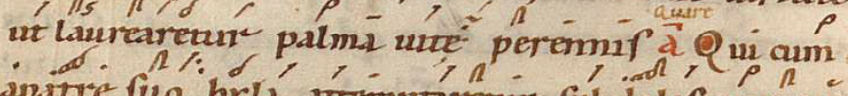

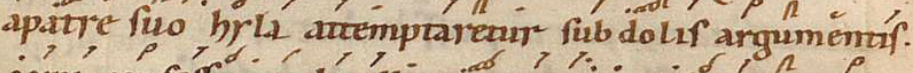

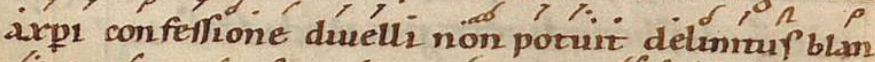

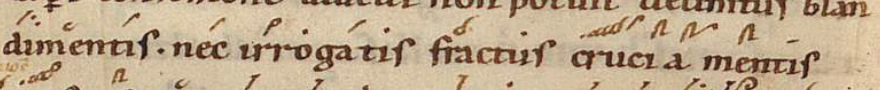

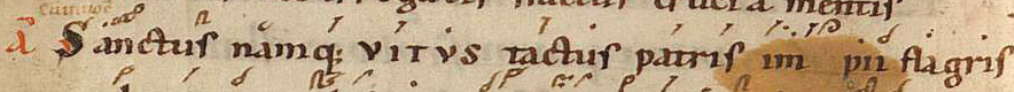
ad parrem celeftem cordir intentionem dirgebat.

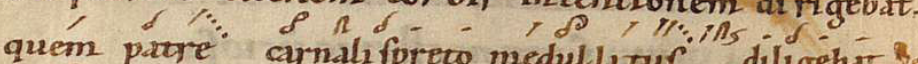
ar of..., carnalifpreco medull our diligebat. Bet a X protani nommif inimicum domine aunc deftruxifi

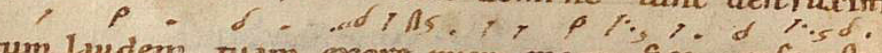
cum laudenn taum exore puen magni fice perfecufti.

Fig. 2: Munich, Bayerische Staatsbibliothek, Clm 536, f. 136v; @ Munich, Bayerische Staatsbibliothek. 
At this point a leaf from an older gospel book has been put in, but the binding material is completed by a half-leaf, on which the Vitus chants continue. On the recto, the responsories for the Second Nocturn, M-R5-R8, are detectable; red V initials, and melismata typical of responsories can be made out. On the verso of the half leaf we have the end of M-R8, then the canticle antiphon at the start of the Third Nocturn, followed by three of the last set of responsories, M-R9-R11 (start). Very little can be seen on the leaf itself, but a great deal more on the offset inside the back board.

We are still short of the end of R11, and final responsory, and Lauds. However, at the front of the book there is another half-leaf, cut the same way as the one at the back, and again a lot can be read from the offset inside the front board. There, we have the end of the Matins responsories, the antiphons for Lauds, and on the verso of the half leaf the two big antiphons for the Benedictus at Lauds and the Magnificat at Second Vespers. One may hope that an undamaged later source with staff notation may some day be discovered.

\section{Schlägl, Stiftsbibliothek, Cpl 262 - Exaltatio crucis}

Since the monastery in Prüll was dedicated to St Vitus there is a good chance that the historia was written there; so far, it has not been found anywhere else. When searching for such chants one relies to a great extent on the immense CANTUS database in Canada. ${ }^{8}$ The larger the database becomes, the more reliable are the indications it gives about concordances and patterns of transmission. As a test case, I may cite some fragments in the library of the Premonstratensian monastery of Schlägl in Austria, north of Passau, quite close to the Czech border. ${ }^{9}$ A few dozen fragments of liturgical music books are preserved there, including two leaves from an antiphoner, now bound at the front and back of a later book, a breviary following the use of Passau. The leaves run consecutively, with chants not for a saint's day but for the feast of the Exaltation of the Cross (14 September) (see Fig. 3). I use this example for two reasons: it demonstrates the usefulness of the CANTUS databases in tracing office chants, and it shows up the lack of comprehensive surveys of neumatic notations.

$8<$ http://cantus.uwaterloo.ca> (accessed 12 Nov. 2019). The project is now directed by Debra Lacoste.

9 For further information on chant sources in the Stiftsbibliothek at Schlägl see Hiley 2019. 


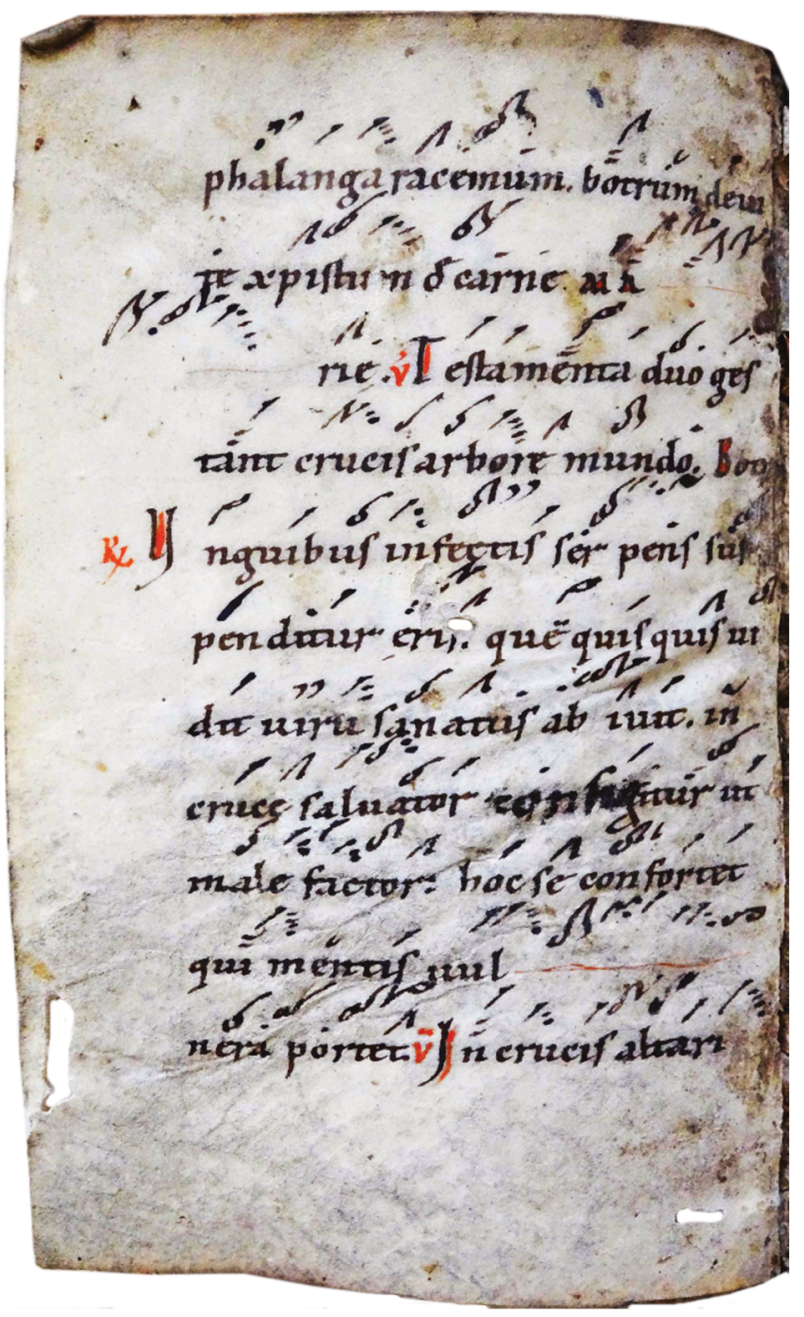

Fig. 3: Schlägl, Stiftsbibliothek, Cpl 262, f. Bv; @ S Schlägl, Stiftsbibliothek.

The original antiphoner was a small book, only about $9 \times 14 \mathrm{~cm}$. In the fragment, there are altogether eight fully notated chants for the First and Second Nocturn of Matins, following the secular, not monastic cursus; of these eight chants, I have found only four elsewhere. Interestingly, the four peculiar to this fragment have texts in hexameters, a poetic technique quite popular in twelfth-century offices (though used earlier as well). It seems possible, therefore, that the author took a previously existing set of chants and added new pieces in a newer style. 
However, his starting point was not an old antiphoner of the Roman-Frankish mainstream, but something more local. Of the four pieces known elsewhere, the responsory Adoramus te Christe is found quite often among South German antiphoners, but the remaining three turn up only in Bohemian sources. One may therefore surmise that the fragment is from a book compiled under Bohemian influence, perhaps brought to Schlägl from Bohemia, since it follows the cursus saecularis, rather than the cursus monasticus obtaining at Premonstratensian Schlägl.

The notation has plenty of individual character which should make at least an approximate localization possible, but unfortunately we do not yet have reliable surveys against which it can be measured. The neumes are obviously German; they slant steeply, which not all varieties of Germanic neumes do. Among the finer details I would single out the final serif on liquescent neumes (cf. Fig. 3: e.g. testament $a$, inguibus, quem); this should in theory be enough to help place the fragments in the chant notation landscape. ${ }^{10}$

\section{Regensburg, Staatliche Bibliothek, Theol.syst.704 - Catherine and Margaret}

The same is true of my third example, a moderately large leaf pasted around the outside of a smaller book. The leaf is now about $16.5 \mathrm{~cm}$ across and $24 \mathrm{~cm}$ high (see Fig. 4). With regard to the notation, we would still classify these as German neumes, although of a quite different variety from the previous example: the musical signs in the Regensburg fragment stand bolt upright, and for most of the vertical strokes the pen moves downwards, from top to bottom. Once again, a detailed map of German chant notations would help localise the fragment.

10 An early witness to this scribal trait is the Reichenau troper, Bamberg, Staatsbibliothek, msc. lit. 5 <https://bavarikon.de/object/SBB-KHB-00000SBB00000127> (accessed 12 Nov. 2019). 


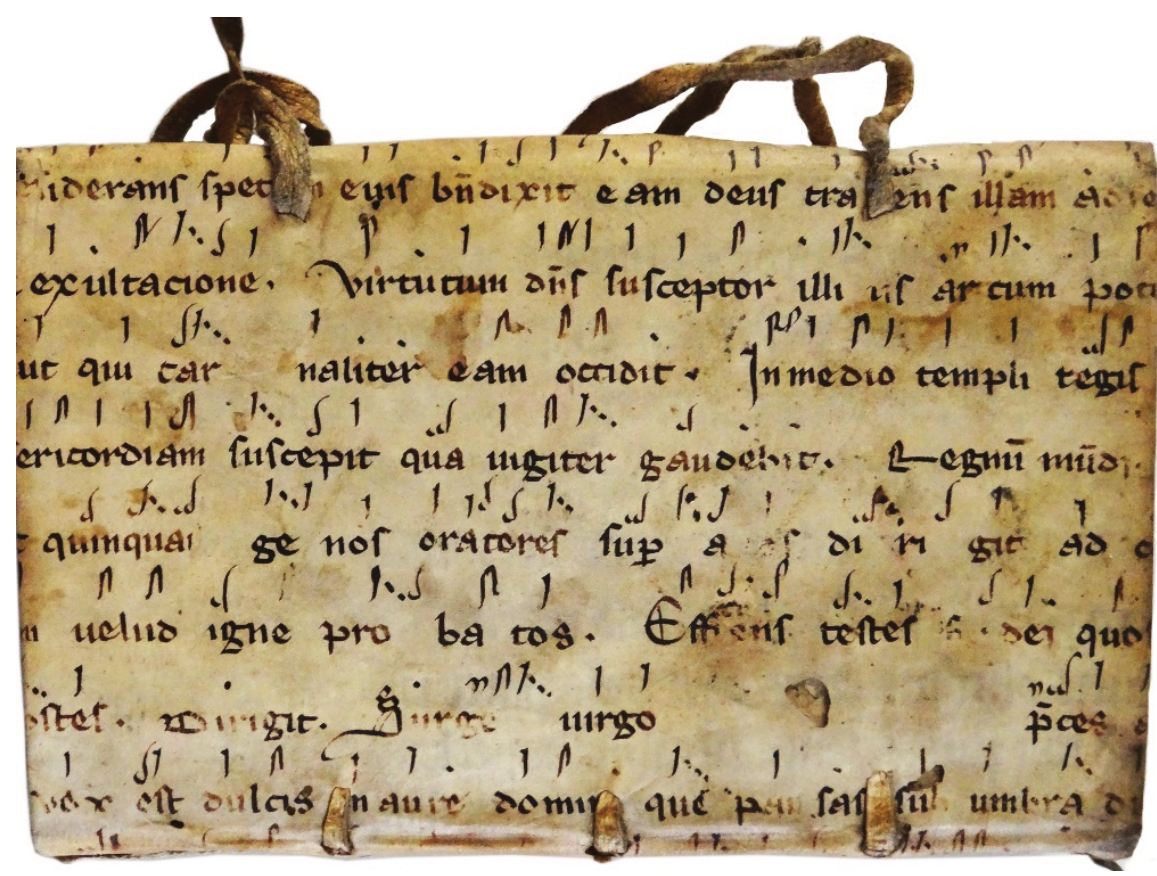

Fig. 4: Regensburg, Staatliche Bibliothek, Theol.syst.704, front cover; @ Regensburg, Staatliche Bibliothek.

The chants belong to the Second and Third Nocturns of Matins, and the start of Lauds (see Table 1). Checking concordances with the aid of the Cantus website produces intriguing results. It turns out that these items are from two distinct offices, both well known in South Germany. The Margaret set usually starts with the Magnificat antiphon Magnificemus Dominum, the Catherine cycle with Magnificat antiphon Inclita sancte virginis. At present, it is not clear how or why the cycles have been combined, or if something similar can be found elsewhere.

Table 1: Contents of Regensburg, Staatliche Bibliothek, Theol.syst.704.

\begin{tabular}{llll}
\hline & & \multicolumn{2}{l}{ Second Nocturn of Matins } \\
$\begin{array}{l}\text { upper } \\
\text { board }\end{array}$ & Ant. 1 & $\begin{array}{l}\text { [De]siderans speciem eius benedixit eam deus } \\
\end{array}$ & Margaret \\
& Ant. 2 & Virtutum dominus susceptor illius arcu & Margaret \\
& Ant. 3 & In medio templi regis [sempiternam] & Margaret \\
\hline
\end{tabular}


Table 1 (continued): Contents of Regensburg, Staatliche Bibliothek, Theol.syst.704.

\begin{tabular}{|c|c|c|c|}
\hline & Resp. 1 & Regnum mundi * [s.n.] & Commune \\
\hline & Resp. 2 & $\begin{array}{c}{[\mathrm{He}] \text { c quinquagenos oratores superatos }} \\
\text { V. Efficiens testes fidei }\end{array}$ & Catherine \\
\hline \multirow[t]{2}{*}{ spine } & Resp. 3 & $\begin{array}{l}\text { Surge virgo [et nostras sponso] } \\
\text { V. [Pulchre Sion filia]. [Gloria P]atri }\end{array}$ & $\begin{array}{l}\text { Catherine and } \\
\text { Margaret* }\end{array}$ \\
\hline & & Third Nocturn of Matins & \\
\hline \multirow{9}{*}{$\begin{array}{l}\text { lower } \\
\text { board }\end{array}$} & Ant. 1 & Dicta sunt gloriosa de te [virgo] & Margaret \\
\hline & Ant. 2 & In populis [annuntiemus] & Margaret \\
\hline & Ant. 3 & Tubis inductilibus psallat omnis spiritus & Margaret \\
\hline & Resp. 1 & Ex eius $t[u m b a]$ * [s.n.] & $\begin{array}{l}\text { Nicholas and } \\
\text { Catherine }\end{array}$ \\
\hline & Resp. 2 & [Vir]go veneranda * [s.n.] & Margaret \\
\hline & Resp. 3 & Felix regina * [s.n.] & Catherine \\
\hline & & Lauds & \\
\hline & Ant. 1 & Passionem gloriose [virginis] Katherine & Catherine \\
\hline & Ant. 2 & $\begin{array}{l}\text { Post plurima supplicia martir alma ad } \\
\text { decollan[dum] }\end{array}$ & Catherine \\
\hline
\end{tabular}

* R. Surge virgo et nostras sponso (602290) is common to Margaret (f. 179v) and Catherine (f. 322v) in Graz, Universitätsbibliothek, MS 30 (St Lambrecht, fourteenth century). ${ }^{11}$

\section{Munich, Bayerische Staatsbibliothek, Clm 17212 - Afra}

MS Clm 17212 in Munich is a very interesting compilation of medieval texts (Marbod, Hildebert, etc.). The book came to the royal library from Premonstratensian Schäftlarn, although it may not have originated there. Inside the front cover is a pastedown and four leaves of disparate content including liturgical chants. The first of the four, measuring $11.5 \times 18 \mathrm{~cm}$, is of significance for the present chapter (see Fig. 5).

11 Available online: <http://143.50.26.142/digbib/handschriften/Ms.0001-0199/Ms.0030> (accessed 12 Nov. 2019). 


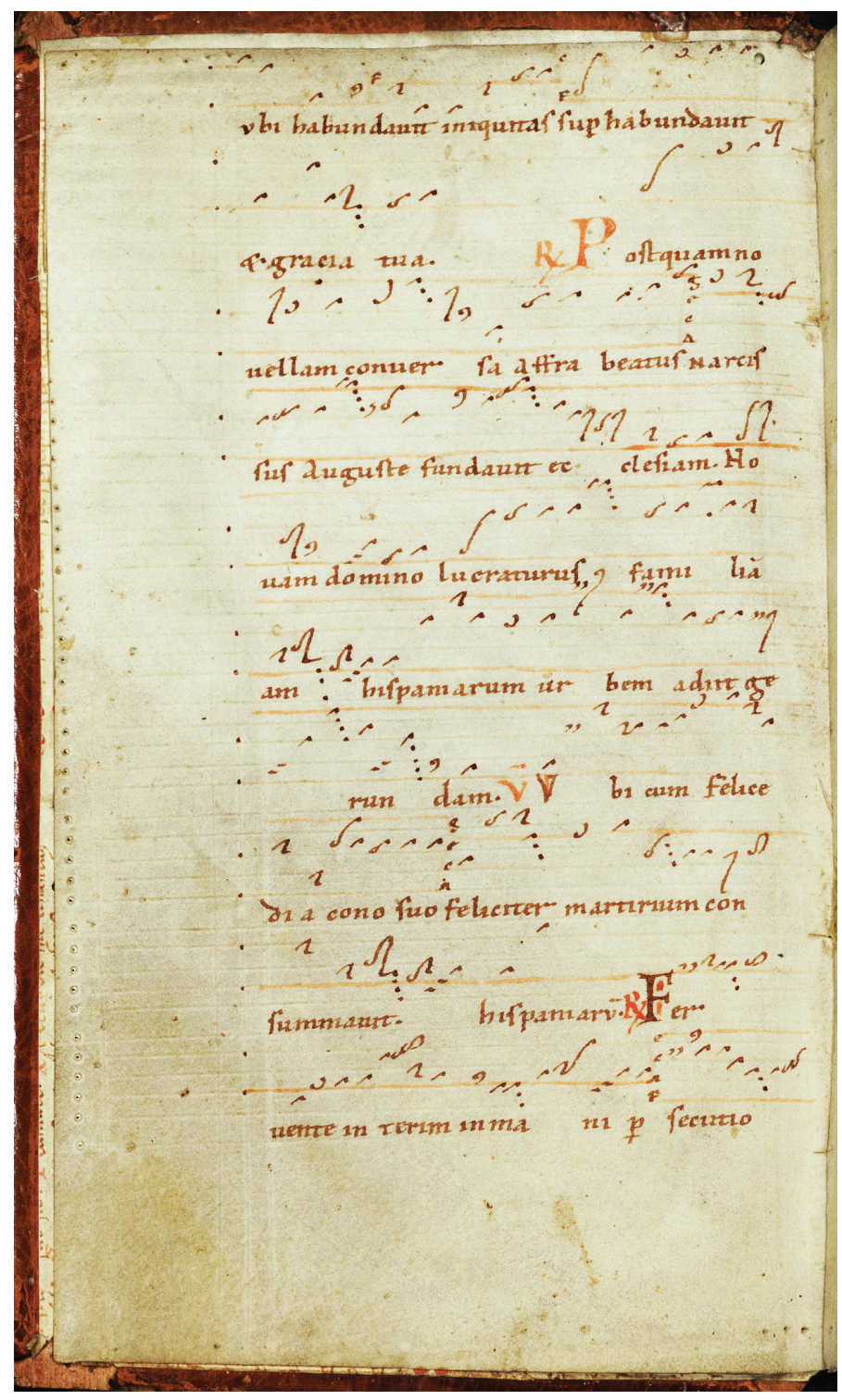

Fig. 5: Munich, Bayerische Staatsbibliothek, Clm 17212, f. Iv; @ Munich, Bayerische Staatsbibliothek. 
The recto is ruled for music but remains blank, the verso has the remains of three responsories from the office of St Afra of Augsburg. ${ }^{12}$ This is a well-known historia, composed by Hermannus Contractus of Reichenau (1013-1054).

We have two other complete offices composed by Hermannus, and all three share a very ornate and adventurous melodic style, far removed from 'classical Gregorian'. Their transmission would have been greatly helped by the use of staff notation, but there is no evidence that Hermannus had them copied this way. He did invent an ingenious interval notation, where the interval from one note to the next, up or down, is indicated, but this seems usually to have been used not for notating complete melodies, rather only as a supplement to normal neumatic notation, for marking isolated tricky intervals. There are several early copies of the Afra chants with unheighted neumes, and one twelfth-century copy with staff notation, Munich, Bayerische Staatsbibliothek, Clm 23037, a notated breviary from the Benedictine monastery of Prüfening, on the outskirts of Regensburg.

Fascinatingly, all other chants in the Prüfening breviary are notated with unheighted neumes, and only Hermannus's difficult chants are written using staff notation. ${ }^{13}$ However, the staff notation in the Prüfening copy, Clm 23037, is not the same as in the fragment Clm 17212. Prüfening follows the old practice of making a distinction between single low notes and single high notes, punctum and virga, whereas all single notes in the fragment are written as small barbs ('uncinus'), or upside-down ticks. This is a well-known distinction, one of several, between neumes descended from the old German type found in St Gall, or Regensburg, or Quedlinburg, and a type related perhaps rather distantly to the old North-East French type sometimes called 'Messine' (from Metz) or 'Lotharingian'. Prüfening was one of several houses affiliated to the reform monastery of Hirsau in the Black Forest, and houses of this group use the German type of early staff notation. The other type is found among other places at Ottobeuren (Clm 9921), and we find it in Klosterneuburg on the Danube north of Vienna. But it was also used in Augsburg (Vienna, Österreichische Nationalbibliothek, 573; Munich, Bayerische Staatsbibliothek, Clm 22025 [flyleaf]; and the music theory collection Wolfenbüttel, Herzog August Bibliothek, Gud.lat.334). ${ }^{14}$ It is distinctly possible that the fragment Clm 17212 was also written in Augsburg, specifically at the monastery of St Ulrich and Afra, in which case it would constitute the oldest known source from that monastery with chants of its patron saint. What I cannot explain is why the Afra chants start in the middle of a responsory on the verso side of the leaf.

12 I am most grateful to Henry Parkes for bringing this fragment to my attention.

13 Edition cited in n. 2 above. On the change of notation see Schlager 1984.

14 Szendrei 1992; Klugseder 2008b, 72-75. 


\section{Munich, Bayerische Staatsbibliothek, Clm 12027 - George}

Finally, I come round in a circle to Regensburg again, or more specifically to Prüfening, and two other leaves with the abbey's early staff notation. Clm 12027 is a large collection of sermons copied by Johannes Kopp, monk and later abbot of Prüfening, dated 1468. The flyleaves, one at the front and one at the back, are from an antiphoner, certainly of the twelfth century. They are nearly continuous, a bifolio between the two is lost (see Fig. 6, Table 2).

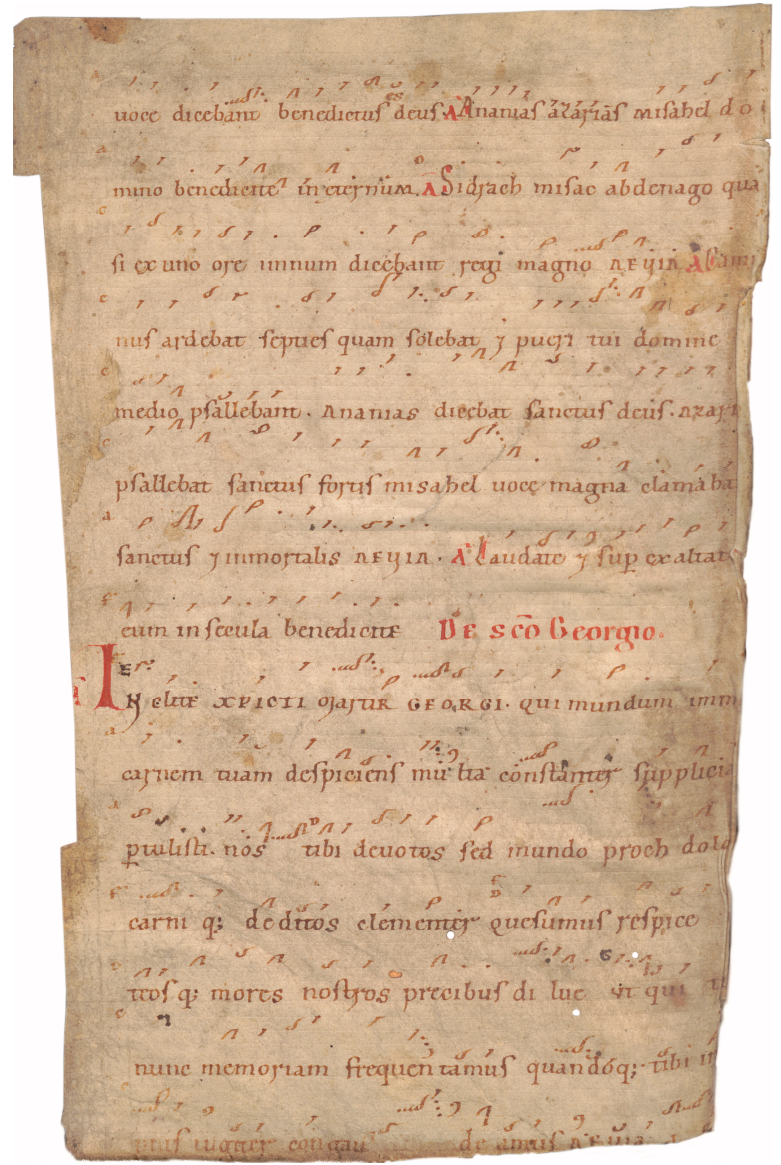

Fig. 6: Munich, Bayerische Staatsbibliothek, Clm 12027, f. Iv; @ Munich, Bayerische Staatsbibliothek. 
Table 2: Flyleaves in CIm 12027.

\begin{tabular}{lll}
\hline flyleaf at front $[\mathrm{A}]$ & recto & George, Officium Defunctorum \\
& verso & Ad Benedicite, George \\
flyleaf at rear $[\mathrm{B}]$ & recto & De Prophetis \\
& verso & De Prophetis \\
Correct order: $\mathrm{Bv}, \mathrm{Br}, \mathrm{Av}, \mathrm{Ar}$ & \\
\hline
\end{tabular}

$\mathrm{Bv}$ [De Prophetis]

[R. Super muros tuos Iherusalem. V. Qui reminisci]mini domini ne taceatis

R. Muro tuo inexpugnabili. V. Erue nos Domine in mirabilibus tuis

R. Sustinuimus pacem et non venit. V. Peccavimus cum patribus nostris

R. Misit dominus angelum suum et conclusit ora leonum. V. Misit deus misericordiam suam

R. Angustie [mihi sunt undique]

$\mathrm{Br} \quad[\mathrm{R}$. Angustie mihi sunt undique ..... l]egem dei mei. V. Si enim hoc egero mors

R. Laudabilis populus quem dominus. V. Beata gens cuius est dominus

R. Genti peccatrici populo. V. Esto placabilis

R. A facie furoris tui Deus. V. Converte nos Deus

R. Qui celorum contines thronos

Av [A. Tres pueri iussu regis .....] voce dicebant benedictus Deus

A. Ananias Azarias Misahel domino

A. Sidrach Misac Abdenago quasi ex uno ore

A. Caminus ardebat septies quam solebat

A. Laudate et superexaltate

De Sco Georgio

Inclite Christi martir

Ar [A. Egregius Dei martyr Georgius .....] per illum Dominus

[Pro Defunctis]

R. Scio enim quia redemptor meus vivit. V. Surgent

[Ottosen 85]

R. Putasne mortuus homo rursum. V. Ecce in pulvere [Ottosen 70]

R. Ne tradas.

[Ottosen 58]

There is in fact no good reason to query the provenance of the fragment, found in a Prüfening book, employing early Germanic staff notation like that of the Afra office in the Prüfening breviary $\mathrm{Clm}$ 23037, and with two chants for the monas- 
tery's patron saint George. But it is worth identifying all the pieces on the fragment more exactly.

The two leaves would originally have come towards the end of an antiphoner. The leaf now at the back comes first, what is now the verso side was originally the recto. In their original order, the chants start with responsories for the series De Prophetis, that is, for the Sundays at the end of the church year, just before Advent and the start of a new annual cycle. Matins lessons through the summer are taken from various books of the Old Testament: Kings, Ecclesiastes, Job, Tobit, Judith, Maccabees, Ezekiel [or Prophets], and the responsories take verses from the same books.

Some chants are gone with the lost bifolio, because the next items on the fragment are Benedicite antiphons for Lauds (L-A4) for the same Sundays, we have the last five of the group. We can compare these responsories and antiphons with completely preserved series, using the CANTUS lists and checking other sources - I have been able to compare about two dozen sources from the South German area. There must originally have been seventeen responsories in the series. The first three and the last five are lost from the fragment, and those that are left correspond with the selection and order in just two other sources known to me: the Prüfening breviary Clm 23037, and an antiphoner from Zwiefalten, Karlsruhe, Badische Landesbibliothek, MS 60. Karlsruhe 60 is a well-known member of a group of sources from the Hirsau congregation of Benedictine monasteries, of which Prüfening was also a member. Fewer sources include the Benedicite antiphons, but Karlsruhe 60 is one of those few, so we can complete this fragmentary series as well.

At this point the two antiphons for St George appear, and finally the start of another series of responsories, for the Office of the Dead, only three items out of the nine which were usual, but nevertheless significant. The Danish liturgist Knud Ottosen, building on the work of Gabriel Beyssac, Michel Huglo and others, compiled lists of these responsories from over 2000 sources. ${ }^{15}$ Although only just over 100 different responsories are involved, their selection and order is very variable. ${ }^{16}$ Our fragment has only two responsories and the start of a third, Ottosen numbers 8570 58. The result is surprising. Only one source in Ottosen's lists begins thus: Munich, Bayerische Staatsbibliothek, Clm 26221. Ottosen gives no

15 Ottosen 1993.

16 The work of comparing series across so many sources was transformed when Robert Klugseder transferred them from Ottosen's book into a database, where they can be sorted very conveniently. <https://www.uni-regensburg.de/Fakultaeten/phil_Fak_I/Musikwissenschaft/cantus/index.htm> Databases Responsories for the Office of the Dead (accessed 12 Nov. 2019). 
provenance for the manuscript, nor does the summary catalogue of the Bavarian State Library. ${ }^{17}$ In fact, Clm 26221 is one of the group of ten more or less unknown breviaries now shelved together, several of which come from Regensburg. ${ }^{18}$ Both $\mathrm{Clm} 26221$ and the previous item in the catalogue, $\mathrm{Clm} 26220$, turn out to be from Prüfening: they both have special prayers for Bishop Otto of Bamberg, founder of the monastery, both observe Otto's translation day as well as his main feast, and both rubricate the two St George antiphons for the canticles at Lauds and Vespers. One is still left with the question of why the two George antiphons should have been copied at this point in the original antiphoner. It may be hoped that, with the expansion of resources for comparing both fragments and more fully preserved sources, an answer to this question and to some of the others raised above will be found. Time will tell.

\section{Abbreviations}

$\begin{array}{ll}\text { 1V } & \text { First Vespers } \\ 2 \mathrm{~V} & \text { Second Vespers } \\ \mathrm{A} & \text { Antiphon } \\ \mathrm{Ab} & \text { Antiphona ad Benedictus } \\ \mathrm{Am} & \text { Antiphona ad Magnificat } \\ \mathrm{L} & \text { Lauds } \\ \mathrm{M} & \text { Matins } \\ \mathrm{R} & \text { Responsory }\end{array}$

\section{References}

Berschin, Walter (1975), 'Uodalscalcs Vita S. Kuonradi im hagiographischen Hausbuch der Abtei St. Ulrich und Afra [Uodalscalc-Studien I]', in Freiburger Diözesan-Archiv, 95: 82106.

Hauke, Hermann (ed.) (1994-2013), Katalog der lateinischen Fragmente der Bayerischen Staatsbibliothek München, 3 vols, Wiesbaden: Harrassowitz.

Hiley, David (2014), 'The historia for Sts Marinus and Anianus composed at Rott am Inn in Bavaria', in Robert Klugseder (ed.), Cantare amantis est. Festschrift zum 60. Geburtstag von Franz Karl Praßl, Purkersdorf: Hollinek, 163-171.

17 Schmeller 1881, II/4, 178.

18 The library has scores of such books, still awaiting investigation. 
Hiley, David (2015a), The Office of Saint Julian of Le Mans by Letald of Micy (ca. 1000) (Wissenschaftliche Abhandlungen/Musicological Studies 65/25), Lions Bay: Institute of Medieval Music.

Hiley, David (2015b), 'Gens laudum titulis concrepet Anglica: The Proper Office for St Oswin, King of Deira', in John Bergsagel, David Hiley, and Thomas Riis (eds), Of Chronicles and Kings. National Saints and the Emergence of Nation States in the High Middle Ages, Copenhagen: Museum Tusculanum Press, 251-270.

Hiley, David (2019), 'Die Choralhandschriften in der Stiftsbibliothek Schlägl im Kontext der süddeutschen liturgischen Traditionen', in Ulrich G. Leinsle and Petrus A. Bayer (eds), Stift Schlägl - Beiträge zu Geschichte und Kultur, Linz: Wagner, 49-84.

Hiley, David, and Walter Berschin (2004), Hermannus Contractus (1013-1054): Historia sanctae Afrae martyris Augustensis (Wissenschaftliche Abhandlungen/Musicological Studies 65/10), Ottawa: Institute of Medieval Music.

Klugseder, Robert (2008a), Historia Sancti Quirini, Historia Sancti Chrysogoni aus dem Benediktinerkloster Tegernsee (Wissenschaftliche Abhandlungen/Musicological Studies 65/14), Ottawa: Institute of Medieval Music.

Klugseder, Robert (2008b), Quellen des gregorianischen Chorals für das Offizium aus dem Kloster St. Ulrich und Afra Augsburg (Regensburger Studien zur Musikgeschichte 5), Tutzing: Hans Schneider.

Ottosen, Knud (1993), The Responsories and Versicles of the Latin Office of the Dead, Aarhus: University Press.

Schlager, Karlheinz (1984), 'Neumenschrift und Liniensystem. Zum Notationswechsel in der Münchener Handschrift Clm 23037', in Musik in Bayern, 39: 31-41.

Schmeller, [Johann] Andreas (1881), Catalogus Codicum Latinorum Bibliothecae Regiae Monacensis, vol. II/4: Codices num. 21406 - 27268 complectens, München: Bibliotheca regia [repr. Wiesbaden: Harrassowitz, 1969].

Szendrei, Janka (1992), 'Linienschriften des zwölften Jahrhunderts auf süddeutschem Gebiet', in László Dobszay, Ágnes Papp, and Ferenc Sebő (eds), Cantus Planus. Papers Read at the 4th Meeting, Pécs, Hungary, 3-8 September 1990, Budapest: Institute for Musicology of the Hungarian Academy of Sciences, 17-54.

Toy, John (2009), English saints in the medieval liturgies of Scandinavian churches (Henry Badshaw Society, Subsidia 6), London: Henry Bradshaw Society.

Yeager, Travis N. (2009), 'The Old Office of St. Emmeram: A New Source Recovered', in Barbara Haggh and László Dobszay (eds), Cantus Planus. Papers Read at the 13th Meeting, Niederaltaich, Germany, Aug. 29 - Sept. 4 2006, Budapest: Institute for Musicology of the Hungarian Academy of Sciences, 683-689. 